Article

\title{
"It Isn't Race or Nation Governs Movement": New Writers' Press and the Transnational Scope of Irish Experimental Poetry in the 1960s and 1970s
}

\section{Will Fleming}

Department of English Language and Literature, University College London, London WC1E 6BT, UK; will.fleming.17@ucl.ac.uk

Received: 30 September 2019; Accepted: 15 November 2019; Published: 20 November 2019

\begin{abstract}
In this paper, I seek to contribute to the resurrection from critical obscurity of an overlooked tradition in contemporary Irish poetry: namely, that of small-press poetic experimentalism. Taking as a case study the Dublin-based New Writers' Press (NWP, established 1967), I will interrogate the absence of virtually any mention of small Irish experimental presses in critical narratives of late modernist poetry of the British Isles in the 1960s and 1970s. By using an array of insights gleaned from the many letters, typescripts and other ephemera in the NWP archive housed at the National Library of Ireland, such absences in scholarship are explored in the context of what the press' founding editors faced in navigating the small Irish poetry market of the mid-twentieth century. Through this archival lens, the reasons why a cohesive avant-garde network of British and Irish poetic experimentalists never materialised are analysed, and an argument for how Irish poetic experiments of the last half century have not received anywhere near the same degree of critical attention as those of their British counterparts will emerge. In the first half of this paper, I focus on the Irish commercial poetry scene in the 1950s and 1960s, ultimately illustrating how narrow and competitive it was in comparison to the British market, as well as the peculiar individual context of an Irish campus magazine, Trinity College's Icarus (1950-). This will in turn suggest that the absence of presses such as NWP from critical accounts of late modernist poetic experimentalism may well be due to editorial decisions made by those Irish presses themselves. In the second half of this paper, I foreground some important archival evidence to review a number of instances in NWP's history in which it comes close to forging alliances with presses within the more cohesive British experimental scene, though it never manages to do so. Drawing on this evidence, I present an archival basis for counterarguments to the possible conclusion that the responsibility for the general absence of Irish presses from narratives of small-press experimentalism lies with those Irish presses themselves.
\end{abstract}

Keywords: late modernism; avant-garde; poetics; distribution; Irish poetry; British poetry revival; Icarus magazine; experimental poetry; small-press poetry; transnational poetry; New Writers' Press; Fulcrum Press; Trigram Press; Association of Little Presses

The NWP initiated the real end of parochial lyricism in Ireland. The stuff still gets written \& gets awards \& reputations \& blocks the progress of better work but NWP was a watershed.

(Scully 1987¹)

1 Many of the quotations used in this paper came from various materials accessed in the New Writers' Press Archive at the National Library of Ireland (Collection List No. 85; MSS 40,118-40,179). As many of these quotations are taken from personal letters directly, they are denoted by their send date for in-text citations-in the form of " $\mathrm{d} / \mathrm{m} / \mathrm{yy}$ " - where applicable. In the few instances where a quote is taken from an undated letter, the year in which to the best of my ability I have determined 
NWP was at the forefront of internationalising poetry in Ireland in the 60s/70s.

(Hogan 1997)

New Writers' Press (NWP) was founded in Dublin in 1967 by Michael Smith and Trevor Joyce-two Dublin-based poets in their twenties whose skin in the Irish poetry game was, at that point, still, by a mainstream standard at least, gossamer thin. Neither had published a book yet, neither belonged to a collective of poets such as the contemporaneous Belfast poets (Heaney, Mahon, Longley) or the previous generation of Dublin-based poets whose centre of gravity was the Palace Bar on Fleet Street, and only Smith had even a rudimentary knowledge of "the technicalities of printing and publishing", gleaned during "a brief stint working for a Dublin newspaper" (Joyce 1995, pp. 266-67). Joyce-almost five years Smith's junior and by his own admission the greener of the two when they met in 1966-recalls the indistinguishable underpinnings of their relationship and the press' foundation as follows:

Mike already had some poems published in journals, which impressed me greatly. I'd been trying to 'crack' poetry for a couple of years, but without thought of publication, but Mike tore my stuff apart, and sent me off to read the best poetry and criticism of the previous fifty years. It was like an ice-cold shower. (Joyce 2016, p. 1)

Evidently it was not a coterie mentality nor a craftsman's sense of technical skill-in producing books or poems-nor indeed a publisher's desire to reach a particular public that underlay their first organic step into the stream of Irish poetry publishing. Instead, it was something much more fundamental, if comparably private: a poet's innate desire to develop their own craft, informed by the preceding work of those they most admired. As I will clarify in this paper in due course, this mode of beginning would continue to inflect the central ethos of NWP through its most brazenly existentialist phase of activity in the 1970s.

Smith and Joyce began NWP, then, with seemingly modest practical ambitions to match their small-press status-first, in fact, simply as a convenient means of getting their own poetry into print: "we each had enough to fill a small book, and in the summer of '67 we founded New Writers' Press to publish them" (Joyce 2016, p. 1). Once the press had actually begun operations, its modus operandi dilated into the promotion of a slightly wider, though no less particular cast of poets: "the publisher has decided to bring out a series of small books each of which will give a young poet the chance of finding the audience so necessary to him" (Smith 1967, p. 6). What these statements of intent quietly imply is what Joyce calls "the stagnancy of the Irish poetry scene relative to what had happened in the U.S. and Europe" by 1967, with its solitary, exclusive poetry press, Liam Miller's Dolmen (Joyce 1995, p. 276); what they omit, however-and latter-day scholars have illustrated - is that such NWP books and such NWP poets would by and large espouse what are variously termed "experimental", "avant-garde" or "innovative" poetics ${ }^{2}$. Based on the two retrospective accounts in the opening quotations above, an uninitiated reader could be forgiven for assuming that the acronym "NWP" once represented a publishing bastion for such experimental poetries, emanating from both Ireland as well as further afield simultaneously. Despite publishing Irish experimentalists such as Thomas MacGreevy and Brian Coffey alongside foreign poets such as Jack Spicer and Jorge Louis Borges within its first decade of activity, however, such an assumption is somehow deferred in contemporary scholarship. By 1987, in fact, Michael Smith himself seems mindful of this dissonance between perceptions and reality-as Scully remonstrates, "Michael—you grossly underestimate yr [sic] success with [NWP] [ ... ] I fail to

they are sent is given. A comprehensive list of the entire archive collection on New Writers' Press at the National Library of Ireland is available for further reference at the following web address: http://www.nli.ie/pdfs/mss $\% 20 l i s t s /$ newwriters.pdf. In addition, I have also quoted extensively from various back issues of Trinity College Dublin's literary magazine, Icarus (1950-). These were accessed directly at the Early Printed Books Section of the Trinity College Berkeley-Lecky-Ussher Library in Dublin.

2 For examples of this, see (Lloyd 2016, p. 11; Goodby and Edwards 2002, p. 176; Joyce 1995, p. 278; Joyce 2003, pp. 157-58)—all of whom use these various epithets interchangeably. 
see where you failed" (Scully 1987). In this paper, I seek to excavate the proof of that "success" from an otherwise buried and abridged history.

A critical consideration of NWP's operations in the 1960s and 1970s is rare but by no means uncharted scholarly territory ${ }^{3}$. What sets the present paper apart, however, is that it seeks along the way to recast our entire understanding of how experimental poetry proliferated in the late twentieth century and, in so doing, to convert a narrative of self-professed "failure" for one subset of contemporary Irish poetic output into a story of intrepid beginnings. Michael Thurston and Nigel Alderman reserve only one sentence for NWP throughout their 342-page study on post-war British and Irish poetry-even confusing Trevor Joyce for Michael Smith in the process (Thurston and Alderman 2014, p. 63). Similarly, C.D. Blanton's essay specifically on "Transatlantic Currents" in the dissemination of mid-century experimental poetry presents an essentialised account of the exchange between America and Britain, while Ireland, the island situated between these two nations geographically, is only cursorily represented-again, by one sentence on NWP (Blanton 2009, p. 149). Ken Edwards, in an essay that asks "how and why poets in the British Isles since 1960 have seized the means of production" (Edwards 1996, p. 19), fails to acknowledge NWP at all—or, for that matter, any other press from that most tenuously British of British isles, Ireland. NWP similarly receives no mention across the 761 pages of The Oxford Handbook of Contemporary British and Irish Poetry (Robinson 2013) either. In this paper, I seek a redress of such abbreviated histories. By absorbing insights and revelations from the many letters, typescripts and other ephemera housed in the NWP archive at the National Library of Ireland, I build upon new foundations such a redress, equipped with a wealth of salvaged knowledge about the press' operations, ideals, interactions and impediments throughout its early reign. That is, the conclusions to come derive directly from the drawers and filing cabinets of the press-an otherwise seemingly untapped resource. Under this archival influence, then, the following analysis will not simply address what NWP did do as a promoter of experimental poetry in Ireland; rather, through reclaiming buried archive materials, it will ruminate on what it did not do to further that agenda beyond national borders. While this may sound more like a negative critique of NWP's pursuits in the 1960s and 1970s, there is a lot to be gleaned from asking why such an agenda might not have been furthered, from considering that there may be more to it than potential obstinance or reticence on NWP's part. As Dorn writes, "it isn't race or nation governs/movement" (Dorn 1967, p. 19); can such a proverb reasonably be applied to Irish poetic experiments of the 1960s and 1970s?

The point that I seek to make in this paper is that NWP's marginal place in such narratives as Blanton's, Edwards's and others', is predicated on material historical facts of circulation as opposed to poetic and editorial ambitions. NWP's effective exclusion from such historical accounts is presumably justified by the simple fact that it was absent from the major distribution channels and transnational alliances of experimental poetry presses at a time when, as Blanton notes, dialogues between national or regional experimental communities were widespread and far reaching (Blanton 2009, p. 148). Such exclusion, however, forecloses on an array of critical considerations. Firstly, it declines to ask why NWP was siloed off from this transnational community despite engaging in a lot of the same activities, publishing material that might very reasonably have been published from within that community and adopting at times uncannily similar practices as the small presses that variously composed it. Secondly, it implicitly overlooks the many opportunities and near-misses that NWP did have in aligning itself meaningfully with experimental scenes abroad—facts only learnt through archival revelations.

In the following paper, I devote a section to each of these two overlooked critical considerations. The first demonstrates the extent to which "parochial lyricism" did plague the mid-century commercial Irish poetry scene and the correlative extent to which NWP committed itself to unsettling that paradigm. By considering the restrictive conditions of the Irish commercial scene to which NWP was beholden against the comparable freedom experienced outside those boundaries by an Irish campus magazine,

3 Such a feat is variously undertaken by the likes of (Davis 2000; Lloyd 2016; Falci 2012; Keating 2017). 
in this section, I argue that NWP's absence from a transnational experimental poetic community might have been an inevitability embedded in the structure of the Irish poetry marketplace at the time. In the second section, I reconsider NWP's project of "internationalising poetry in Ireland" in light of the findings of the first. Through recourse to many pieces of archival evidence that suggest- though do not therefore confirm-affinities between NWP and the concurrent British small-press scene, I examine whether such affinities never materialised because of entrenched iconoclasm on NWP's part or ignorance on the part of that British scene. The goal is to reconstruct an archival bedrock that underlies the patchy and endlessly interrupted history of an entire subset of Irish poetic circles since 1960: namely, those beneath the banner of small-press poetic experimentalism.

\section{Buy Gall; Put It in Your Ink: Addressing the Mid-Century Irish Poetry Scene}

Don't let lassitude lose you—-there's the whole Dublin establishment and scandalpit to kick the arse of.

(Coffey 1970c)

Yes, not neurotically nationalist will do very well.

(Coffey 1970d)

Following a relatively apolitical first few years of operation, the 1970s heralded the beginning of a "second phase of activity" for NWP (Joyce 2003, p. 159)—one which took for its editorial tack the above imperatives and postures suggested by one of the press' greatest allies, Brian Coffey. From the beginning of the decade, Michael Smith, its founder-editor, had begun to use his editorials in the press' newly-established house magazine The Lace Curtain (1969-1978) as a platform for the sort of "arse-kicking" policy that Coffey sanctions, for "a general assault on Irish provincialism" (Joyce 2003, p. 158). Far from being an arbitrary "assault", Smith's critical line arose from an overwhelming atmosphere of frustration and inevitability. It was a by-product of seeking to promote experimental poetry in a country whose commercial poetry market was saturated with traditionalism - to the exclusion of any other brand of poetry (Goodby and Edwards 2002, p. 174). The commercial market was, however, not the only channel for publishing poetry at the time. The rise of the campus magazine in the 1950s was one avenue which, by 1970, had enabled certain poets in Ireland to circumnavigate the obstacles of the commercial scene in bringing an array of alternative poetries before an Irish audience (Price 2013, p 186). By comparing the endeavours of Trinity College Dublin's literary magazine Icarus (1950-) with those of NWP, the differences in campus and commercial ventures crystallise. In showing that Icarus was markedly freer to pursue its aims than NWP and comparing such freedom to that experienced concurrently by a budding small-press poetry scene in Britain, the contrasting limitations of NWP's operations suggest its necessary absence from a more transnational community of small presses.

Smith's iconoclastic editorial stance can be traced back to a significant, if "good-humoured", rift in NWP's administration in the early 1970s, as recounted by his co-editor Trevor Joyce (Joyce 1995, p. 279). As Joyce puts it, by the summer of 1970,

We [he and Smith] both complained of the rarity of good new writing, and both felt the urge to do something about it. Our disagreement concerned the means: Mike felt that relevant and acute criticism could do the job, while I [ ... ] decided that the only way to get poetry written of the sort I would be interested in reading was to write it myself [ ... ]. As a result, I withdrew increasingly over the course of Lace Curtains 3 and 4, from active involvement in the running of the press [ ... ]. (Joyce 1995, p. 279)

The implication here, as Joyce continues, is that such "relevant and acute criticism" would be levelled solely and vehemently on the Irish poetry scene, to the exclusion of nearly all other subjects of poetic discourse-the "arse-kicking" Coffey advocates. A series of "rebarbative attacks" on the commercial 
Irish poetry scene thus "made explicit, in retrospect, what had emerged as NWP's editorial policy" (Joyce 1995, p. 281). That "editorial policy" is enshrined in invectives by Smith across Lace Curtains 3 and 4 (Smith 1970, 1971a) and The Denver Quarterly (Smith 1971b). For a broad example of what a characteristically punning Brian Coffey calls "the gall" in Smith's ink (Coffey 1970d), the first of these delivers:

Now if there is any one thing on which it is possible to hang a thesis in a discussion of serious Irish poetry during the last twenty years that thing seems to me to be the gradual disappearance of nationalism and its concomitant bogus traditionalism. [... ] the best poetry written in Ireland during the last ten years or so has been written by poets for whom the Irish literary thing has had little or no interest, or when considered by them, was dismissed in disgust as something thoroughly soiled by sham and insincerity, and a thing that was, at any rate, artificial and irrelevant. (Smith 1970, p. 6)

Smith and Joyce's divergent approaches in this rift articulate respectively, "the pressing realities [in Ireland] of either representing the postcolonial nation to itself, or of forging the artwork directed to transcending mundane politics" (Goodby and Edwards 2002, p. 175). For a firmer understanding of Smith's commitment to the first of these, it is necessary to go back a couple of decades to its origin as a conscious preoccupation for Irish poets. John McAuliffe offers an account of the mid-century commercial scene that suggests social and material conditions from which this preoccupation may have emerged:

The 1950s were a transitional period for Irish poets and publishers. Existing journals and publishers went out of business early in the decade. [ ... ] Irish poets were generally published in England [ ... ] In 1951 the journals Envoy and Poetry Ireland had ceased publication; [ ... ] The Bell rarely published poetry in the years before it closed in 1954. [The 1950s were therefore] a time when Irish culture can be characterised as insular and impoverished, and when-for poets—the complexity of Yeats's legacy and example became more apparent. (McAuliffe 2012, pp. 225-26)

As a diagnosis of an intensely narrowed commercial scene, this is just as applicable to the context in which NWP was founded seventeen years later-as though the course of Irish poetry had plateaued over the span of two decades. As Joyce notes, the only other active Irish press by 1967 was Liam Miller's Dolmen—an operation that "leaned heavily on the legacy of Yeats" (Joyce 1995, p. 276) and for whom "an experimental desire to problematize the lyric self and poetic language was not among its priorities", as it was for NWP (Goodby and Edwards 2002, p. 176). The fact that there was only one other commercial press in Ireland, whose "small stable of writers" (Joyce 1995, p. 276) favoured the legacy of Yeats-the inevitable synecdoche of the "bogus traditionalism" Smith attacked-justifies NWP's iconoclastic line. It suggests that any press seeking to publish anything outside of that "bogus" tradition would first have to carve out a new niche for itself within this truncated commercial channel. Such a prerequisite did not haunt campus magazines such as Icarus, however. The seemingly stunted growth of the Irish commercial scene between the 1950s and 1967 runs counter to Icarus' evolution into a magazine that, between its inception in 1950 and relative maturity in 1967, had developed a genuinely transnational scope. By comparing the two, the inevitability of Smith's "rebarbative" stance towards the commercial marketplace and the effect this had on NWP's transnationalist potential emerge.

Firstly, there are numerous liberties that the campus magazine enjoys that are unavailable to independent commercial ventures such as NWP. Whereas an independent press depends most heavily on an audience for its financial base-especially in a climate of Arts Council stringency (Joyce 1995, p. 281)—campus magazines need not usually worry about either. Their audience, at least in theory, is in-built in the university student body, while their operations tend to be subsidised, if not altogether bankrolled, by university administrations. Both are true for Icarus, which has all but ensured its longevity; as its founder records in its tenth-anniversary issue in 1960, 
Icarus, helped by a tiny grant from the Board and by a generous guarantee, has kept going for ten years without a break, and we believe that it is the only literary magazine set up in the British Isles since the war that can advance such a claim. (Reid 1960, p. 12)

In addition, campus magazines are usually able to avoid becoming wedded to one particular agenda, because, as is the case with Icarus, they tend to cycle through editorial teams on a regular academic-yearly basis, as Reid acknowledges in the same piece, "Icarus [has] no aesthetic creed, no overall design" (Reid 1960, p. 10). This means that one editor's aesthetic may be directly contradicted just as easily as it may be maintained between years.

For evidence of this fact that Icarus avoids becoming a mere mouthpiece for a certain cause, we may look to the editorial of its thirteenth issue in 1954. In it, chairman W. Gordon Simpson refutes the contention that Icarus could and even should be inflected in its content by the fact of its emanating from an Irish university - a contention offered, rather astonishingly, by then-Trinity lecturer in English, Donald Davie:

Dr. Davie is asked to review the twelfth issue of [Icarus], and he does so, making much of the fact that it contains very little that is Irish. These are some of his exact words [ ... ] "the current number of Icarus surely makes a queer showing as the literary magazine of an Irish university [ ... ] after all, Trinity is not an English provincial university, and it is a pity when Icarus gives the impression that it is". (Simpson 1954, p. 5)

Against such a nationalist agenda for the magazine, Simpson offers the following riposte, bolstered by the aforementioned implication that such an agenda does not and should not fall within the remit of a campus magazine:

Icarus has published a great deal of material which slid easily into the category of "Irish writing", but it is true that a great deal more of its content has been "cosmopolitan". If Trinity had been leading a revival of Irish letters Icarus would have played a leading part in this. At the moment she is merely [ ... ] doing her best not to be as sterile as she is supposed to be. (Simpson 1954, p. 7)

Davie would eventually deliver his proposed nationalist agenda, however, through becoming chairman himself for issues 18 and 19 in 1956-a testament to the protean nature of the campus magazine aesthetic in itself. Unsurprisingly, issue 18's editorial echoes his earlier zeal for a conspicuously Irish Icarus, advocating for a series of "tributes" to the likes of Synge, O'Casey, Yeats "and other literary giants of the past" across future issues-a process whereby readers could find "in the genius of the past [ ... ] inspiration for the future" (Cole 1956, p. 1). This, coupled with the appearance in issue 19 of a previously unpublished Yeats poem (Yeats 1956, p. 2), as well as an original piece by Louis MacNeice (MacNeice 1956, pp. 19-20), reflects both McAuliffe's and Joyce's earlier hints at the lingering dominance of Yeats and the accompanying spectre of a "bogus traditionalism". However, the nationalist line espoused here is a threatened one; it represents a defence mechanism against the anti-identitarian praxes espoused by the likes of Simpson, which the campus format affords its editors. It is significant more as an indicator that such hauntings of that tradition are not so firmly ensconced and immovable for an Irish campus magazine as they are by Smith and Joyce's testimony in the commercial realm of poetry publication in Ireland as late as 1970. Davie's nationalist position is therefore the exception rather than the rule, and one need only consult the broad scope of attitudes across its early editorials and the dramatic swing of its aesthetic pendulum from year to year to recognise that. This itself suggests the difference of impediments on either side of the line separating a campus magazine from a press navigating the commercial realm.

This divergence is most fully realised in yet another, more militant assault on the Davie-nationalism line intermittently toed by early Icarus editors. It comes in issue 46 of 1965, edited by Iain Sinclair; its editorial begins with the apropos dictum, "Change comes eventually to everything. So too with that hardy and hoary 15-year perennial-Icarus" (Sinclair 1965, p. 1). What makes Sinclair's new direction 
for Icarus so pivotal in the context of this paper is not just its disavowal of certain previous, retrograde editorial policies, but specifically where it points to instead for its very underpinnings:

It is not enough to replace one set of prejudices with another. Merely to remove the school of Yeats and set up something more contemporary [ ... ] would not be enough. [ ... ] To choose your influences well, like Eliot, is the best possible start for a poet. To choose America is to do this. English verse outside America this century is negligible. (Sinclair 1965, pp. 2-3)

From here, Sinclair lists various poetic innovations, heralded by, most prominently, Charles Olson, as the harbingers of a remedy for such otherwise "negligible" poetics. The gravity of Sinclair's polemic would only be fully realised in issues 48 and 49 (both produced in 1966), however, where Olson receives pride of place among the editors' genealogy of contemporary poetry. In issue 48 , this is literally the case, with his name appearing at the centre of a mock-up contemporary poetry family tree (Anonymous 1966), while in issue 49, the reprinting of three of his Maximus Poems-through the permission of his American publisher, Jonathan Williams, specifically (Olson 1966a, 1966b, 1966c)—consolidates Olson's importance.

This turn to America as the beacon of a new experimental poetics aligns perfectly with what was happening on the fringes of literary output in Britain concurrently-in what Ken Edwards calls a "self-help publishing movement" of small presses, led by experimental poets (Edwards 1996, p. 21). It mirrors what C.D. Blanton records as the "two critical narratives" espoused by this movement: "the persistent relevance of a modernist style and the linguistic fact of a transatlantic connection" (Blanton 2009, p. 148). These were foundations for this movement-otherwise termed the "British Poetry Revival" (Falci 2015, pp. 92-93)—focused poetically by "what Charles Olson would dub 'COMPOSITION BY FIELD, as opposed to inherited line, stanza, over-all form'”, broadly speaking (Blanton 2009, p. 144). If these similarities between Icarus and the British Poetry Revival tentatively suggest an unlikely affinity between an Irish campus magazine and the concurrent small-press scene in Britain, however, a further detail solidifies it. The inclusion in issue 49 of poetry by Gael Turnbull represents the moment at which Icarus not only comes closest to a communion with this British scene but, in fact, becomes the only Irish little magazine, campus or commercial, to make any meaningful contact with it by 1966. Turnbull was a progenitor of that British self-help movement-his Migrant imprint was responsible for the importation of Olson's Maximus Poems - the very prism, therefore, through which such a "transatlantic connection" propagated in the late 1950s (Blanton 2009, p. 148).

The ability to produce a magazine in Dublin in 1966 that solicited and included poetry by Turnbull (Turnbull 1966), alongside three Maximus Poems supplied by Olson's American publisher directly, is telling of the seemingly endless limits to Icarus' aesthetic freedom. Moreover, it betrays the sense that amid a dominantly "insular" Irish poetic community, there did exist a faction within it that subscribed to this nascent transnational crusade, by now "throwing bodies, books, and ideas around the world in new patterns, and into new combinations-much too quickly for the old commands to keep their purchase" (Pattison 2012, vol. viii). These patterns, furthermore, were even reciprocated in the case of Icarus. In the same way that it placed experimental works from Britain and America before an Irish audience, Icarus received attention from within those contexts as well. Most notably, in Peter Finch's Cardiff-based little magazine, Second Aeon (1966-1975), Icarus is listed within the magazine's regular "small press scene" feature-a comprehensive list of presses and magazines that promoted poetic experimentalism around the world (Finch 1975, p. 203). Bob Cobbing, whose contributions to the sustenance of a British mid-century poetic avant-garde are inestimable, recalls in 1995, "Second Aeon, of course, was very, very good at documenting what was going on" in the global experimental scene 
throughout its relatively short reign (Cobbing 2000, p. 317) $)^{4}$. Icarus both added to and benefitted from the energy of this vortex of poetic activity across the Irish Sea.

The aesthetic freedom Icarus enjoyed in the 1960s, then, is not unlike that which this British self-help publishing movement enjoyed concurrently-if the respective conditions through which that freedom came to each nevertheless differed. Whereas for Icarus the need for money and an audience is never a problem due to its university subsidies, "generous guarantee" and adjacent student body, for the British small-press scene a similarly viable space began to open up within a commercial channel: "By the 1960s, the very success of such brands as Eliot's Faber \& Faber, long aged into respectability, had opened a space for a new network of small presses and little magazines to occupy" (Blanton 2009, p 149). Similarly, as Reid and Simpson's earlier sentiments corroborate, Icarus is not beholden to any nationalist agenda; nor, anymore, was this British avant-garde scene by the 1960s:

One of the immediate effects of the agitated, charismatic activity of these groups was to diminish the authority of such traditionally powerful discourses as nation [ ... ] in determining the course of a poet's work. (Pattison 2012, vol. viii)

Hence, that "transatlantic connection" became economically and ideologically viable in Britain-not unlike how a dialogue with Britain became available to Icarus.

How is it the case, then, that Icarus experienced a similar degree of aesthetic liberty to that of the British experimental scene in roughly the same period that Joyce and others remember as an otherwise intensely "conservative" era for Irish poetry (Joyce 2003, p. 157)? John Goodby and Marcella Edwards provide the answer. Due to a "different economics of scale" to those of British or American commercial landscapes, they argue, "the resources of the small Irish poetry scene are bitterly contested, policed by narrow networks of patronage, the result, in turn, of historically impoverished cultural and civil spheres" (Goodby and Edwards 2002, p. 175). The inference here is that there is a "refusal to allow space" to experimental writing in Ireland when the commercial poetic community is scarcely large enough to adequately facilitate even "the discourse of mainstream poetry" with which Smith took umbrage (Goodby and Edwards 2002, p. 175). They continue by corroborating Blanton's earlier point about a "space" finally becoming available to a British avant-garde by the 1960s: "By way of comparison, the British poetry mainstream, itself averse to experimentalism, is large enough to accommodate 'crossover' points with avant-garde currents without feeling threatened" (Goodby and Edwards 2002, p. 175). The reality of such a contrast, they conclude, is that conversely, "Irish writers have been forced to ceaselessly negotiate their writing in an interstitial way. Lodged between the two globally-dominant anglophone cultures, they have been forced to learn vigilance towards forms of external reception" - the "proof", they lament, that "rootedness [and] identity" still hinder commercial Irish poetic output "in the world of transnational capital" (Goodby and Edwards 2002, p. 176). Such a rooted, identitarian position is precisely that which Smith was forced into espousing in navigating a treacherous commercial Irish poetry scene-a position which cannot properly look beyond its borders before first addressing the restrictions rife within them. As Smith self-consciously puts it in a letter to John Montague:

I'm afraid that too often as a critic, I am over-mindful of literary politics, thrown off balance by a narrow-minded missionary zeal [ ... ]. It comes, I'm sure, from working in an atmosphere of hostility and apathy. (Smith 1972)

Icarus was not subject to such "hostility and apathy" because it endured in a peculiar auxiliary wing of production, disconnected from the constrained commercial space of poetic output in Ireland-able,

4 It is worth noting also that Iain Sinclair himself cites Second Aeon as his own inlet into this British scene upon his return from studying in Dublin in the late sixties: "Second Aeon, edited by Peter Finch, out of my natal city Cardiff, was a good noticeboard on which to discover what was going on, and to make contacts" (Sinclair 2016, p. 61). Tony Lopez also had virtually the same experience: "I can't remember where I got hold of the magazine Second Aeon, but that was my first source of wider information and it gave me a sense of what was possible" (Lopez 2016, p. 65). So too, Peter Barry: "Since around 1972-1973 I had been sending poems to poetry magazines I knew were OK, because they were listed in Peter Finch's journal Second Aeon" (Barry 2016, p. 111). 
therefore, to do what Smith and others could not. It is telling, for instance, that Sinclair would only manage to "float magazines that never got beyond the proof stage" in Ireland's limited commercial structure after finishing with Icarus (Sinclair 2013, p. 12), before relocating to Britain where he could - via the doors opened by Finch's Second Aeon—successfully renew his small-press publishing efforts through his own Albion Village imprint (Sinclair 2016, pp. 61-62). Sinclair recollects those very limits to the Irish commercial scene with regret:

Living in Dublin for four years kept us at a certain distance from what can now be seen as the beginnings of "The British Poetry Revival" (Eric Mottram) or The Children of Albion (Michael Horovitz). Neither were we part of that useful adventure in correspondence, the circulation of The English Intelligencer. Or the fraught weekend gatherings of warring tribes in Northumberland cottages: Cambridge formalism, Newcastle wildboy. (Sinclair 2016, p. 61)

Such strictures were specific to Ireland, severed wholesale from some of the foundational limbs of this late modernist poetic network. Britain was not only infinitely freer than Ireland in this regard, but it represented, as Sinclair implies here, a stage upon which experimental poetry was genuinely thriving.

The contrast between this freedom and its lack in the British and Irish commercial scenes respectively maps onto a number of activities of Smith's that bespeak his-and therefore NWP's-rebarbative stance. For instance, the spark that ignited his "editorial policy", as Joyce recalls, was his editorial in Lace Curtain 3, occasioned by the publication of Kennelly's (1970) Penguin Book of Irish Verse (Joyce 1995, p. 281). Smith contends that Kennelly's selection of poets is "happily discountable" for its traditionalist leanings and "straightjacketing imbecility" in omitting poets whose work ventures outside the scope of Ireland's "parochial lyricism" or deviates from that "Irish literary thing", to use his own phrase (Smith 1970, p. 9). The appearance four years later of John Montague's Faber Book of Irish Verse (Montague 1974) only compounded Smith's frustrations for similar reasons. The overriding issue in this equally monolithic anthology was the particular omission of Brian Coffey. This reignited another adversarial campaign that originated with Lace Curtain 4: the retrieval of "an earlier generation of Irish experimentalists" of the 1930s-Brian Coffey among them-from obscurity (Joyce 2003, p. 159). These two obstacles-the proliferation of national poetry anthologies unrepresentative of non-mainstream contemporary poets and the ill-fated struggle to reclaim earlier experimentalists from obscurity in their own nation—did not exist to the same extent for British experimental poets concurrently. British anthologies such as the aforementioned Children of Albion: Poetry of the Underground in Britain (Horovitz 1969) or British Poetry since 1945 (Lucie-Smith 1970)-both published by Penguin - managed to include such contemporary experimental poets as Turnbull, Tom Raworth and Lee Harwood, all of whom were prominent fixtures in the small-press scene. In the case of the latter anthology, these and others of that scene are even interspersed with such titanic national poetic icons as Philip Larkin and John Betjeman, reiterating Goodby and Edwards's contention about the potential for "crossover' points" between a "mainstream" and certain "avant-garde currents" in Britain. The presence, also, of the likes of Basil Bunting and David Jones in that same anthology proves that whereas Smith met obstinance in his attempts to rejuvenate the reputations of early Irish experimentalists, the same cannot be said of the British Poetry Revival's championship of its own perceived precursors-both Bunting and Jones were after all published by Britain's "premier small press of the late 60s to early 70s", Fulcrum Press (Edwards 1996, p. 22), thus immortalising them as the ur-poets of the British small-press movement.

When scholars condense the entire panoply of experimental poetic endeavours in late-twentieth-century Ireland to one limited sentence, they overlook everything revealed above. An interested reader would be incredibly hard-pressed to find a single mention of Icarus in a critical study of post-war Irish experimental poetry, and yet, it was, by 1966, the only Irish literary institution of any kind successfully building relations with British and American experimentalists; Ireland's only buoyant literary venture floated amid such "transatlantic currents". These histories, therefore, inevitably sell short Ireland's propensity for promoting and producing experimental poetry in the period. They do not ask important questions of NWP's absence from a larger small-press community, 
thus perpetuating the inference that it was a "failure". They decline, in turn, to examine the necessity of its iconoclastic position. The aim from here, then, is to do just that-to consider whether it was such an iconoclastic position or ignorance on the British side that kept NWP isolated from a wider transnational small-press network.

\section{Navigating the Central Whirl of London: Transnational Near-Misses}

No one in London (not even Bernard Stone and Better Books) has heard of the "New Writers' Press".

(Yablonski 1970)

By the way, how are sales over here? I ask because I haven't seen Writers' Press publications in the usual bookshops in Charing Cross Road.

\section{(Galvin 1971)}

The inevitably iconoclastic editorial policy adopted by NWP from 1970 may speak to the above quotations. In the remainder of this paper, I will foreground that policy as one possible explanation for why NWP came close to, but never fully attained, a dialogue with the British small-press scene, as Icarus did. The potential foil to such an explanation will be that it might as easily have been ignorance on behalf of that British scene, that the "central whirl of London", to which Coffey refers as a nexus of experimental poetry by the 1970s (Coffey 1970c), and its many satellites never garnered the energy necessary to assimilate the experimental murmurings of NWP into its gravitational pull. Logistically speaking, after all, NWP seems just as ripe for entrance into a transnational community of experimental presses as factions from Britain by 1969. As Blanton writes of the specifically British-American "transatlantic connection" at this time, "traditions form dialectically, not only as native products but also as an archive of imported goods" (Blanton 2009, p. 152); NWP exemplified both. Alongside publishing the idiosyncratically experimental Irish poetries of Trevor Joyce and James Hogan (under the pseudonym Augustus Young), for instance, NWP had, by the late 1960s, begun to pursue one of its "founding aims": publishing "experimental poetry in English from outside Ireland" (Joyce 1995, p. 278). By the time, in fact, the quotes from Yablonski and Galvin above had been uttered, NWP had already been responsible for the importation and publication of the San Francisco Renaissance poet Jack Spcier's Billy the Kid (Spicer 1969b), "then tied up by litigation in the US" (Joyce 1995, p. 278). What, then, was missing?

If such London bookshops as Better Books or Bernard Stone's Turret had no knowledge of NWP by 1970, it means NWP's "most secret" Billy the Kid had eluded the London market somehow (Siverly 1969). This is significant: not only were Better Books and Turret omphaloi for the British small-press scene for their stocking of experimental poetry (Miller and Price 2006, p. 121), Jack Spicer was one of that British scene's principal American influences (Fisher 2015, p. 42). Of particular importance, in fact, was the appearance on British shores in 1969 of A Book of Music (Spicer 1969a; Fisher 2015, p. 56). That this book should have been published and presented to the British scene by the same person through whom NWP, according to Liddy (Liddy 1969b), acquired the manuscript and rights to Billy the Kid —Graham Mackintosh of San Francisco's White Rabbit Press-and in the very same year, is astonishing. It intimates the, at times, diaphanous degrees of separation between the British and Irish experimental scenes in the 1960s and 1970s. By considering NWP's many near-misses with the British scene, such as this one, extracted directly from archival materials, the remainder of this paper takes shape. It will interrogate why such logistical proximities did not eventually translate into a "connection" between the British and Irish small-press scenes as it had for Britain and America for instance.

By jumping ahead to the mid-1970s, Smith's rebarbative editorial stance initially looms as the more likely explanation. At this time, another Irish poet affiliated with and published by NWP, Geoffrey Squires, sends Smith an admonitory letter, exposing the anachronism of his iconoclastic critical line:

Compared with past ages, we have a marvellous accessibility of information, alternative pasts, modes, and no one is restricted on that score anymore, if he has a certain amount of 
energy. Also, printing and publishing have become cheaper-witness the proliferation of all sorts of small papers and mags. So although there may be some truth in the complaint that the literary scene is controlled by a few ignorant people, I think that particular barrier can be broken through quite easily. (Squires 1975)

In this final sentence, we recognise the reference to Smith's enduring critical maxim in the 1970s that the likes of Kennelly and Montague - "a few ignorant people"-were the sentinels "controlling" the Irish literary scene, with the implication that such an obstacle must be met head on. Squires, however, suggests renovating such an approach in the idiom of the British self-help publishing movement; his concluding sentiment echoes the sense that in Britain, at least, as I have already established in this paper, there was a way around the mainstream publishing channels "if [one] had a certain amount of energy" by this time. Squires goes on to suggest the particular path by which Smith could achieve this flanking manoeuvre in Ireland:

There is of course the foreign [ ... ] option, and I can see people looking to France, East Coast US, West Coast US, Latin America etc for this, a kind of cultural transfusion process. For myself, I think I have gained a great deal from reading Olson, [Robert] Duncan and those who talk about 'fields'. (Squires 1975)

Not only, then, does Squires suggest precisely the kind of "cultural transfusion process" by which the likes of Turnbull fostered Britain's "transatlantic connection" with America in the late 1950s, he even volunteers the very poets and poetics championed by Turnbull and that British faction-not to mention mid-1960s Icarus - as its prospective agents. If, however, Squires offers Smith the means for a direct line into a transnational experimental community here, Smith's draft response of 1975 in the NWP archive rejects them. Instead of embracing a "foreign option", as NWP had in 1969, Smith doubles down on his inward-looking endeavour to reinter the legacy and example of the Irish "experimentalists" of the 1930s within a contemporary Irish consciousness. Though he extols the fact that a poet's "inheritance may be more than local" by the 1970s in Ireland, "ideally", he concludes, Irish poets should operate under the influence "of what has been thought and felt by men before [them]" (Smith 1975)—a rather conspicuous reference to those 1930s modernist precursors. Such a stance surely exists at quite a remove aesthetically from the NWP that published Billy the Kid six years previously.

The gulf separating Smith's fortified critical stance in 1975 and the fact of NWP's publication of Billy the Kid in 1969 therefore demands context. What changed in the interim? Recourse specifically to archive materials attached to The Lace Curtain over this six-year period traces how NWP's policy of "importing" experimental works declined, while various archived correspondences thereafter consider the state of its exportation policy of its own experimental offerings concurrently. Brian Coffey's relationship to Smith and NWP holds many of the keys to both. Unlikely as it may seem based on the "arse-kicking" he advocated in 1970, Coffey was massively influential in seeking to de-escalate Smith's editorial policy further into the decade and in expanding NWP's operations beyond inward-looking polemics. As he writes to Smith just a year after the publication of the overtly political Lace Curtain 4,

What I dream of [for The Lace Curtain] is something equivalent to La Nouvelle Francaise emanating from Dublin and not tied to politics in any way. The best young writers respectful of language's potential from every country [... ]. The circumstances of the common market should mean for intelligent Irish writers an immediate entry on the stage where human events are tried. We ought to be ready for this and have formats which draw foreign writers to us. (Coffey 1972)

With the "arse" of "the whole Dublin establishment and scandalpit" seemingly sufficiently "kicked" in Lace Curtain 4, Coffey turns his energies to a new "dream", encompassing both the exportation and importation sides of NWP's operations at once. Envisioning The Lace Curtain as a platform simultaneously launching "intelligent Irish writers" into a transnational "common market" and 
"drawing foreign writers" to an Irish audience, this "dream" represents an apolitical model whereby Smith could have shed his obsessive iconoclasm.

The component parts of such a model were being fed to Smith via Coffey from as early as March of 1971. Alongside advocating for the inclusion of such Irish poets as Lorna Reynolds, Augustus Young and even Smith himself in the fifth instalment of The Lace Curtain, Coffey furnishes Smith with a list on 1 April 1971 that "shows what [he has] in hand for Lace Curtain 5 or definitely promised" (Coffey 1971a). Among those pledged submissions, Coffey lists work by Asa Benveniste, Bob Cobbing, Tom Raworth and Thomas A. Clark-all of whom ran their own British small presses in the 1960s and 1970s and were notable actors in the British Poetry Revival (Edwards 1996, p. 21). Coffey's agenda was pretty clear. In the dissonance between Coffey's prospective table of contents for Lace Curtain 5 and the eventual finished product, however, exists another of those near-misses (Smith 1974); while Benveniste's piece is included in the fifth Lace Curtain, which does not appear until some three years later in 1974, Cobbing, Raworth and Clark are missing. If the conclusion that these pieces might never have found their way into Smith's possession seems reasonable—given that some are, in Coffey's words, only "promised" - evidence from the archive problematises this. Firstly, Clark's piece intended for Lace Curtain 5, "The Poem as Knowledge" (Clark 1971), sits unused and miscategorised among an archived folder of materials relevant to Lace Curtain 4; in addition, in an adjacent folder also listed as relevant to Lace Curtain 4, an unattributed poem entitled "Infancy in Fact" appears to be the piece solicited by Raworth-also apparently misplaced ${ }^{5}$. If Smith had these pieces well in advance of Lace Curtain 5 's publication, as such archival evidence suggests he did, why did he omit them? The answer may lie in the three-year gap between the fourth and fifth instalments of The Lace Curtain. In July 1972, for one, fiscal insolvency threatened the press, as various newspaper clippings alluding to funding appeals in the archive imply (Newspaper Clippings (Various) 1972)—which may explain the interim suspension of operations. Furthermore, as we have already seen, between 1971 and 1974 Smith was gradually bolstering his assault against lingering Irish provincialism - a policy presumably only further galvanised by the press' financial frustrations in the early 1970s. If Smith's stance had transitioned into one that, by 1975, explicitly rejected the viability of Squires' "foreign option", the absence of several otherwise locked-in foreign poets from Lace Curtain 5 increasingly makes sense.

The importation side of Coffey's "dream", therefore, deteriorates gradually over those three years; the correlative exportation side, however, remains to be considered. As we saw, Coffey sought to bring the work of both Benveniste and Cobbing before an Irish audience in Lace Curtain 5, but this would not be the only role that he envisioned both playing for NWP's internationalism. Within the span of two months in 1970, Coffey advised Smith to seek the counsel of both, in their capacities as shrewd and powerful mediators of the British small-press scene. On 16 July 1970, in advising Smith on United Kingdom distribution networks for NWP titles, he writes, "Why not try ASA BENVENISTE", appending the address of his Trigram Press and adding, "Asa [ ... ] has been very active here [in London] on behalf of all The Little Presses" (Coffey 1970b). The alliance implied here suggests that Coffey already considered NWP as one among "all The Little Presses" by 1970, disregarding incidental details such as national provenance. Nowhere, however, is such a perception given more formal weight than in his advice to Smith two months prior to get his books listed in the catalogue of Cobbing's Association of Little Presses (ALP). The ALP was a vital formal crux for "advice and exchange", around which a disparate collective of British small presses was assembled together and thus an experimental tradition given some semblance of formal structure (Falci 2015, p. 92). Unsurprisingly, then, its

5 While it is impossible to confirm this is a Raworth poem, the speaker— "Tommy"—-shares several biographical details with Raworth, including being born in London just before the Second World War (specifically, "Cancer's child I was, July"- Raworth's star sign and birth month), having an apparently undetected heart defect ("diagnosis fell on a deaf ear") and having ancestors involved in revolutionary affairs in Dublin in 1916 (Raworth 1971). Furthermore, Benveniste confirms that Raworth definitely did send poetry despite having "vowed not to contribute to magazines anymore" in an archived letter to Coffey (Benveniste 1971). 
catalogue "does business for one, as about 5000 copies are distributed", Coffey notes, illustrating that such a move would not only be extremely beneficial to NWP's foreign distribution, but would bring its list of books to the specific attention of countless likeminded British poets and presses (Coffey 1970a). For one reason or another, however, Smith seemed to ignore Coffey's advice, and the ALP catalogue—Little Press Books in Print (Cobbing 1971)—went to press and circulated without mention of NWP. We can assume, moreover, that the onus for such an omission is on Smith, because Coffey would renew his advice to use Cobbing's influence in Britain to the same end time and time again, though most desperately in 1973: "Cobbing [ . . . ] is a decent man, knows your name and work, and [ ... ] could put you onto some useful people" (Coffey 1973).

Determining whether Smith took the advice of a plethora of other correspondents regarding the distribution of NWP books to British bookshops specifically, however, is less demonstrable; the presence of their books on British bookshop shelves is virtually untraceable. Nevertheless, scores of letters in the archive contain more suggestions of bookshops to which to export NWP books than this paper has room to reasonably enumerate-for which reason it will confine itself to some important ones ${ }^{6}$. Perhaps the most promising and assured of these leads is Patrick Galvin's pledge to Smith in 1971 that,

As my off-spring is more or less in charge of the poetry section in Better Books he can always give a good push to any publications as good as yours. Not only in the shop, but at the various poetry readings organised by Better Books. (Galvin 1971)

Better Books, as we saw, was an important hub where British experimental poets could buy the work of their peers and foreign influences, and it operated as a focal point for otherwise dispersed poets-not unlike Cobbing's ALP (Miller and Price 2006, p. 121). The use of Galvin's "off-spring", then, would have facilitated the stocking and promotion of NWP books amid a readymade confluence of British experimental poets and publishers; all we know for certain, however, is that by 1970 at least, Better Books had no awareness of NWP's existence according to Andrew Yablonski (Yablonski 1970), with no further indication that it ever would. Both Coffey and Squires would also emphasise the value in getting NWP titles on the shelves of another "significant" bookshop for small presses and little magazines, according to Miller and Price (Miller and Price 2006, p. 121): Compendium in Camden (Coffey 1971b; Squires 1974). James Liddy too would recommend these and several others in a long list of important British and American bookshops to which he boasted connections (Liddy 1969a).

Whether these represent genuine near-misses or merely offhand suggestions, however, is difficult to say. Even if, unlikely as it is, Smith did get NWP books into all of these distribution channels, it is impossible based on archival evidence alone to rule out the possibility that chance could have intervened. They might have simply sat inconspicuously on shelves or may not have been in stock at opportune times in key bookshops. Despite once again reiterating just how close NWP's orbit came to overlapping with those of British collectives, then, these indeterminable variables still lead neither to a consolidation of Smith's iconoclasm, nor to a perceived sense of ignorance or oversight on the part of figures within the British small-press scene as an explanation for NWP's invisibility. One suggestion of such British oversight, however, emerges from Smith's correspondence in 1970 with a key British poet-editor, Tim Longville. Longville was at the time one of two founding editors of the pivotal British small-press and little magazine ensemble, Grosseteste, and therefore responsible for publishing J.H. Prynne, Peter Riley and Roy Fisher, alongside the usual suspects of Turnbull, Clark and Williams across its press and magazine outlets (Miller and Price 2006, p. 157). His first postcard to Smith easily represents the moment at which NWP veers closest to the British scene:

6 This includes overlooking the promises from the likes of James Liddy and Desmond O'Grady to get NWP books stocked in key American bookshops, such as Grolier, City Lights and Oyez (Liddy 1969a; O'Grady 1970). 
I thought I'd write, ask (a) if yourself or any of the folks around you have stuff you'd care to send us [... ]; no guarantees except attention and a friendly reception; (b) if you'd care to swop copy of Lace Curtain for one of GR [Grosseteste Review]: maybe make it a regular thing [ ... ]; (c) send list of things your press has done? (Longville 1970b)

Even more significant than Coffey's gestures towards the likes of Cobbing and Benveniste, Longville's proposal here of a physical "swop" of their respective magazines and his commitment to providing "attention and a friendly reception" to the work of Smith and the "folks around him" represents the potential for a legitimate and even fruitful transnational exchange. Based on Longville's next letter, furthermore, this is an avenue that Smith evidently does not ignore; it is, in fact, Longville's appraisal of the poetry Smith lines up for his consideration for GR on behalf of NWP, and his commentary on Lace Curtain 3, which forecloses on such an exchange.

Regarding the latter, Longville first implicitly targets the redundancy of Smith's iconoclasm, as Squires also would some five years later. He advises that "running a magazine, \& not a Dublin magazine, not an Irish magazine, or not in any limiting sense at least", entails transcending inert criticism and instead promoting "the best [poetry], \& best, the current best (making current what is past \& lost is part of it, surely, but only a part)" (Longville 1970a) — the final parenthetical apophthegm cautiously alluding to Smith's burgeoning commitment to salvaging the work of the Irish experimentalists of the 1930s. Similarly, he reproves the inclusion in the first three Lace Curtains of what he calls "amiable but distinctly second class" American poetry, bearing his preference for the likes of the more formally ambitious work of Louis Zukofsky, Cid Corman and Jonathan Williams-American poets that NWP is "selling short, by silence" in Longville's phrase (Longville 1970a). If this seems like benevolent advice from which NWP could learn to better align itself with the practices of the British scene, however, Longville's comments about the work Smith assembles on behalf of NWP for possible inclusion in Grosseteste Review intercepts such an alignment:

I enjoyed reading the poems—-they are very accomplished—but I see nothing in them (which may be the effect of distance from what they describe) [ ... ]. My blindness most likely, but all I have to work with". (Longville 1970a)

Even in declining to publish the work Smith assembles on behalf of NWP writers for publication in a British little magazine, Longville reduces his rejections to "the effect of distance from" what such Irish poetries are describing. It is not so much a value judgment as it is a reiteration of a perceived fundamental difference between national contexts-a consolidation of the disparities already established between the British and Irish commercial poetry markets. As the only engagement NWP would ever meaningfully have with a powerful force in the British experimental scene in the 1960s and 1970s, furthermore, it is telling that it is ultimately curbed along national borders and the contextual differences either side of them.

It is no wonder then that Smith withdrew increasingly from NWP's early agenda of publishing "experimental poetry in English from outside Ireland" (Joyce 1995, p. 278) from the early 1970s onwards when this was the kind of reception the poetry he marked for export would receive in the closest healthy experimental scene to Ireland. Longville's grounds for passing here also echo poignantly through an assertion Trevor Joyce would make some 33 years after the fact, which reveals just how little has changed in the critical narrative of how Irish experimental poetic traditions emerged and developed in the latter half of the twentieth century. Because it is Joyce's last word in an essay that rigorously details this unfortunate fact, it seems only fitting to make it the last word of this paper as well:

The tug of [James] Joyce, Beckett, and the other poets of the '30s has been strong enough to allow us to feel free of all the hegemonies, whether from Britain, America, Europe or elsewhere, and to confirm to us that writing in Ireland can be radically innovative and independent without privileging any external authorities. We seek from nowhere the franchise to regard 
ourselves as innovators, or to provide a living alternative to those tendencies we find most intimately oppressive. We continue to read American, British, and other radical poetry with respect, sympathy, and sometimes with excitement. We look to have the same openness extended to us. (Joyce 2003, p. 166)

Funding: This research received no external funding. The APC was funded by University College London (UCL).

Acknowledgments: The author's continued research into this subject has been made possible through a Wolfson Postgraduate Scholarship in the Humanities.

Conflicts of Interest: The author declares no conflict of interest.

\section{References}

Anonymous. 1966. “Appendix II". Icarus 16. unpaginated.

Barry, Peter. 2016. "Climbing the twisty staircase". In Clasp: Late-Modernist Poetry in London in the 1970s. Edited by Robert Hampson and Ken Edwards. Bristol: Shearsman Books, pp. 110-14.

Benveniste, Asa. 1971. Personal Letter to Brian Coffey. MS 40, 157/1. Collection List No. 85. Dublin: National Library of Ireland Archives.

Blanton, Charles Daniel. 2009. "Transatlantic Currents". In A Concise Companion to Postwar British and Irish Poetry. Edited by Nigel Alderman and Charles Daniel Blanton. Malden: Wiley-Blackwell, pp. 134-54.

Clark, Thomas A. 1971. The Poem as Knowledge. Undated. MS 40, 171/8. Collection List No. 85. Dublin: National Library of Ireland Archives.

Cobbing, Bob, ed. 1971. Little Press Books in Print. London: Association of Little Presses.

Cobbing, Bob. 2000. "What is important is what is done, not what it is called" (Interview with Wolfgang Görtschacher). In Contemporary Views on the Little Magazine Scene. Edited by Wolfgang Görtschacher. Salzburg: Poetry Salzburg, pp. 299-346.

Coffey, Brian. 1970a. Personal Letter to Michael Smith. 30 May 1970 (30/5/70). MS 40, 119/1. Collection List No. 85. Dublin: National Library of Ireland Archives.

Coffey, Brian. 1970b. Personal Letter to Michael Smith. 16 July 1970 (16/7/70). MS 40, 119/1. Collection List No. 85. Dublin: National Library of Ireland Archives.

Coffey, Brian. 1970c. Personal Letter to Michael Smith. 14 August 1970 (8/9/70). MS 40, 119/1. Collection List No. 85. Dublin: National Library of Ireland Archives.

Coffey, Brian. 1970d. Personal Letter to Michael Smith. 8 September 1970 (8/9/70). MS 40, 119/1. Collection List No. 85. Dublin: National Library of Ireland Archives.

Coffey, Brian. 1971a. Personal Letter to Michael Smith. 1 April 1971 (1/4/71). MS 40, 119/2. Collection List No. 85. Dublin: National Library of Ireland Archives.

Coffey, Brian. 1971b. Personal Letter to Michael Smith. 9 January 1971 (9/1/71). MS 40, 119/2. Collection List No. 85. Dublin: National Library of Ireland Archives.

Coffey, Brian. 1972. Personal Letter to Michael Smith. 9 June 1972 (9/6/72). MS 40, 119/5. Collection List No. 85. Dublin: National Library of Ireland Archives.

Coffey, Brian. 1973. Personal Letter to Michael Smith. 7 July 1973 (7/7/73). MS 40, 119/6. Collection List No. 85. Dublin: National Library of Ireland Archives.

Cole, Connolly. 1956. Editorial. Icarus 6: 1.

Davis, Alex. 2000. "Coda: 'No Narrative Easy in the Mind': The Irish Neo-Avant Garde". In A Broken Line: Denis Devlin and Irish Poetic Modernism. Dublin: University College Dublin Press, pp. 159-76.

Dorn, Edward, ed. 1967. The North Atlantic Turbine. London: Fulcrum Press.

Edwards, Ken. 1996. “UK Small Press Publishing since 1960: The Transatlantic Axis”. Mimeo Mimeo 4: 19-25.

Falci, Eric. 2012. Continuity and Change in Irish Poetry, 1966-2010. Cambridge: Cambridge University Press.

Falci, Eric. 2015. "Late Modernism". In The Cambridge Introduction to British Poetry, 1945-2010. Cambridge: Cambridge University Press.

Finch, Peter. 1975. "Small Press Scene". Second Aeon, 198-267.

Fisher, Allen. 2015. "Skipping Across the Pond: Interaction between American and British Poetries 1964-1972". In Modernist Legacies: Trends and Faultlines in British Poetry Today. Edited by Abigail Lang and David Nowell Smith. New York: Palgrave Macmillan, pp. 41-57. 
Galvin, Patrick. 1971. Personal Letter to Michael Smith. 27 November 1971 (27/11/71). MS 40, 123. Collection List No. 85. Dublin: National Library of Ireland Archives.

Goodby, John, and Marcella Edwards. 2002. "'Glittering Silt': The Poetry of Trevor Joyce and the Myth of Irishness". Hungarian Journal of English and American Studies 8: 173-98.

Hogan, James. 1997. Poetry Conference/Cork/1997: Statement by Augustus Young. 15 April 1997 (15/4/97). MS 40, 124/1. Collection List No. 85. Dublin: National Library of Ireland Archives.

Horovitz, Michael, ed. 1969. Children of Albion: Poetry of the Underground in Britain. Harmondsworth: Penguin Books.

Joyce, Trevor. 1995. “New Writers' Press: The History of a Project". In Modernism and Ireland: The Poetry of the 1930s. Edited by Patricia Coughlan and Alex Davis. Cork: Cork University Press, pp. 276-306.

Joyce, Trevor. 2003. "Irish Terrain: Alternate Planes of Cleavage". In Assembling Alternatives: Reading Postmodern Poetries Transnationally. Edited by Romana Huk. Middletown: Wesleyan University Press, pp. 156-68.

Joyce, Trevor. 2016. "Michael Smith: A Tribute". Irish University Review 46: 1-3. [CrossRef]

Keating, Kenneth. 2017. "Spectres of Irish Poetry". In Contemporary Irish Poetry and the Canon: Critical Limitations and Textual Liberations. Cham: Palgrave Macmillan, pp. 1-53.

Kennelly, Brendan, ed. 1970. The Penguin Book of Irish Verse. Harmondsworth: Penguin Books.

Liddy, James. 1969a. Personal Letter to Michael Smith ("List of Addresses"). MS 40, 136/2. Collection List No. 85. Dublin: National Library of Ireland Archives.

Liddy, James. 1969b. Personal Letter to Michael Smith. 7 March 1969 (7/3/69). MS 40, 136/1. Collection List No. 85. Dublin: National Library of Ireland Archives.

Lloyd, David. 2016. "Introduction: On Irish Experimental Poetry". Irish University Review 46: 10-19. [CrossRef]

Longville, Tim. 1970a. Personal Postcard to Michael Smith. 1 September 1970 (1/9/70). MS 40, 157/6. Collection List No. 85. Dublin: National Library of Ireland Archives.

Longville, Tim. 1970b. Personal Postcard to Michael Smith. 21 February 1970 (21/2/70). MS 40, 157/6. Collection List No. 85. Dublin: National Library of Ireland Archives.

Lopez, Tony. 2016. "Brixton, Wivenhoe, Gonville \& Caius". In Clasp: Late-Modernist Poetry in London in the 1970s. Edited by Robert Hampson and Ken Edwards. Bristol: Shearsman Books, pp. 65-69.

Lucie-Smith, Edward, ed. 1970. British Poetry since 1945. Harmondsworth: Penguin Books.

MacNeice, Louis. 1956. London Irish Chitchat. Icarus 6: 19-20.

McAuliffe, John. 2012. "Disturbing Irish Poetry: Kinsella and Clarke, 1951-1962". In The Oxford Handbook of Modern Irish Poetry. Edited by Fran Brearton and Alan Gillis. Oxford: Oxford University Press, pp. 225-39.

Miller, David, and Richard Price. 2006. British Poetry Magazines, 1914-2000. London: British Library.

Montague, John, ed. 1974. The Faber Book of Irish Verse. London: Faber.

Newspaper Clippings (Various). 1972. MS 40, 157/13. Collection List No. 85. Dublin: National Library of Ireland Archives.

O'Grady, Desmond. 1970. Personal Letter to Michael Smith. 18 June 1970 (18/6/70). MS 40, 145/1. Collection List No. 85. Dublin: National Library of Ireland Archives.

Olson, Charles. 1966a. "I, Maximus of Gloucester, to You”. Icarus 16. unpaginated.

Olson, Charles. 1966b. "The Song and Dance of". Icarus 16. unpaginated.

Olson, Charles. 1966c. "Tyrian Businesses". Icarus 16. unpaginated.

Pattison, Neil. 2012. "Introduction: 'All Flags Left Outside'". In Certain Prose of the English Intelligencer. Edited by Neil Pattison, Reitha Pattison and Luke Roberts. Cambridge: Mountain Press, vols. i-xxiv.

Price, Richard. 2013. "CAT-scanning the Little Magazine". In The Oxford Handbook of Contemporary British and Irish Poetry. Edited by Peter Robinson. Oxford: Oxford University Press, pp. 173-90.

Raworth, Tom (unattributed). 1971. Infancy in Fact. Undated. MS 40, 171/10. Collection List No. 85. Dublin: National Library of Ireland Archives.

Reid, Alec. 1960. “One Man's Icarus". Icarus 10: 10-13.

Robinson, Peter, ed. 2013. The Oxford Handbook of Contemporary British and Irish Poetry. Oxford: Oxford University Press.

Scully, Maurice. 1987. Personal Letter to Michael Smith. 1 February 1987 (1/2/87). MS 40, 157/11. Collection List No. 85. Dublin: National Library of Ireland Archives.

Simpson, W. Gordon. 1954. "Lucky Thirteen"? Icarus 4: 5-7.

Sinclair, Iain. 1965. Editorial. Icarus 14: 1-4. 
Sinclair, Iain. 2013. American Smoke: Journeys to the End of the Light; A Fiction of Memory. London: Hamish Hamilton. Sinclair, Iain. 2016. "Hackney Stopover: Rage in the Eastern Heaven". In Clasp: Late-Modernist Poetry in London in the 1970s. Edited by Robert Hampson and Ken Edwards. Bristol: Shearsman Books, pp. 60-64.

Siverly, William. 1969. Personal Letter to Michael Smith. 8 February 1969 (8/2/69). MS 40,157/11. Collection List No. 85. Dublin: National Library of Ireland Archives.

Smith, Michael. 1967. "Introduction to New Irish Writers". In Sole Glum Trek. MS 40, 173/1. Collection List No. 85. Edited by Trevor Joyce. Dublin: New Writers' Press, Dublin: National Library of Ireland Archives, pp. 5-6. Smith, Michael. 1970. "Irish Poetry and Penguin Verse". The Lace Curtain 3: 3-10.

Smith, Michael. 1971a. Editorial. The Lace Curtain 4: 3-4. [CrossRef]

Smith, Michael. 1971b. "Irish Poetry Since Yeats: Notes Towards a Corrected History". The Denver Quarterly 5: 1-26.

Smith, Michael. 1972. Draft Letter to John Montague. MS 40, 157/12. Collection List No. 85. Dublin: National Library of Ireland Archives.

Smith, Michael, ed. 1974. Table of Contents. The Lace Curtain 5: 3.

Smith, Michael. 1975. Draft Letter to Geoffrey Squires. 13 July 1975 (13/7/75). MS 40, 157/12. Collection List No. 85. Dublin: National Library of Ireland Archives.

Spicer, Jack. 1969a. A Book of Music. Edited by Graham Mackintosh. San Francisco: White Rabbit Press.

Spicer, Jack. 1969b. Billy the Kid. MS 40,173/3. Collection List No. 85. Dublin: New Writers' Press, Dublin: National Library of Ireland Archives.

Squires, Geoffrey. 1974. Personal Letter to Michael Smith. 5 April 1974 (5/4/74). MS 40, 153. Collection List No. 85. Dublin: National Library of Ireland Archives.

Squires, Geoffrey. 1975. Personal Letter to Michael Smith. MS 40, 153. Collection List No. 85. Dublin: National Library of Ireland Archives.

Thurston, Michael, and Nigel Alderman. 2014. Reading Postwar British and Irish Poetry. Chichester: Wiley Blackwell. Turnbull, Gael. 1966. “Dark Outside”. Icarus 16. Unpaginated.

Yablonski, Andrew. 1970. Personal Letter to Anthony Kerrigan. 28 April 1970 (28/4/70). MS 40, 134/1. Collection List No. 85. Dublin: National Library of Ireland Archives.

Yeats, William Butler. 1956. "Reprisals". Icarus 6: 2. 